\title{
Capital Adequacy Ratio (CAR) Analysis, Non Performing Financing (NPF), Third Party Funds, and Interest Rate on Return on Assets (ROA) of Islamic Banking
}

\author{
Budiyono \\ Institut Teknologi Bisnis AAS Indonesia \\ \{budiyono_bk@yahoo.co.id\}
}

\begin{abstract}
The purpose of this study is to analyze the Capital Adequacy Ratio (CAR), Non Performing Financing (NPF), Third Party Funds, and interest rates on Return on Assets (ROA) in Islamic banking (Study at PT BRI Bank Syariah Syariah in 2012-2019). This research is a quantitative study with the data used are secondary data for all variables and financial data contained in the BRI Syariah Syariah financial statements in the 2012-2019 period. Data collected in this study are secondary data so that the techniques or methods of data collection use non-participant observation. The results of this study are the CAR variable has no significant effect on ROA, the NPF variable has a negative and significant effect on ROA, the TPF variable has no significant effect on ROA, the Interest Rate Variable has no significant effect on ROA, the CAR Variable, NPF, DPK and Interest Rates together - the same significant effect on ROA.
\end{abstract}

Keywords: CAR, NPF, DPK, ROA, Interest Rates

\section{Introduction}

The smooth operation of the bank will support the achievement of prosperity, performance, to the level of health and profitability of the bank. In measuring bank profitability performance, there are two factors that affect bank profitability, including external and internal factors. Internal factors include bank financing products, performance financing, asset quality, and capital. External factors include market structure, banking regulation, inflation, interest rates and market growth rates. The factors that affect profitability in this study are internal factors that include financing product factors issued by Islamic commercial banks and performance financing factors (Anto, 2012). Islamic banks or now known as Islamic banks provide payment and payment traffic services and other services whose mechanisms are in accordance with Islamic law. In Indonesia, Islamic banking has emerged since the 90s, at that time Islamic banking was not too much and not very popular, but since the issuance of Law No. 7 of 1992 which was replaced by Law No. 10 In 1998, Islamic banks began to show their existence as financial institutions.

The bank must perform its function properly. Good and correct management of bank functions will have an impact that can provide benefits that can increase the value of bank 
profitability. Profitability is an indicator to determine a bank's financial performance. The ability of banks to increase the value of profitability is able to demonstrate good financial performance. Profitability describes the company's ability to gain profits with existing expertise and sources such as sales, cash, capital, number of employees, number of branches, etc. (Harahap, 2013); (Nuryanto, 2014). Bank Indonesia has decided that one of the bank's profitability benchmarks uses the ROA ratio.

According to Dendawijaya (2001), CAR is a ratio that shows how far all bank assets contain a ratio that shows how far all bank assets that contain risks (credit, inclusion of securities, bills at other banks) are financed from the bank's own capital funds in addition to obtaining funds from sources outside the bank, such as public funds, loans (debt), and others.

NPF is a problematic financing indicator that needs to be considered because it is volatile and uncertain, so it is important to observe with special attention. NPF is one of the performance appraisal instruments of an Islamic bank which is the interpretation of valuation of productive assets, especially in the assessment of problem financing (Tho'in, Tri Irawati, and Lee, 2018); (Simatupang and Franzlay, 2016).

According to Law No. 10 of 1998 concerning Banking in article 1 paragraph 5 has the meaning that bank deposits are funds that have been entrusted by the public to banks based on fund storage agreements in the form of demand deposits, deposits, certificates of deposit, savings, and others. The sources of funds obtained by these third parties have an effect on the ability to meet the volume in transactions which will ultimately increase profits (Fitri, 2016).

Interest rates are conventional instruments used to control inflation, because the higher the inflation the profitability of a company will decrease. Interest rates are divided into two, namely the nominal interest rate and the real interest rate. The nominal interest rate is the interest rate that can be seen and observed in the market, while the real interest rate is a concept to measure the interest rate after the nominal interest rate is reduced by the inflation rate. (Kalengkongan, 2013).

ROA is a ratio that shows the return (return) on the amount of assets used in a company. In addition, ROA provides a better measure of company profitability because it shows the effectiveness of management in using assets to earn revenue (Tho'in, 2019); (Tho'in, 2020); (Winda et.al, 2020); .The word bank comes from the word banque which comes from French, and from the word banco which comes from Italian which means crates, cabinets, and benches. Basically, the understanding of Islamic banks is a financial institution whose main business is providing financing and other services in the payment and circulation of money operated in accordance with Islamic law. Therefore, banking efforts are always related to the issue of money as the main tool (Yudianan \& Fetria, 2014). Therefore, the bank's efforts are always related to money which is its main merchandise (Sudarsono, 2003).

The hypothesis is a conjecture or a temporary answer to the identification of problems in research. The hypotheses compiled in this study are as follows:

H1: CAR has a significant effect on ROA.

H2: NPF has a significant effect on ROA.

H3: Third Party Funds has a significant effect on ROA.

H4: Interest Rates have a significant effect on ROA.

H5: CAR, NPF, DPK, and Interest Rates significantly influence ROA. 


\section{Research Method}

This type of research in this thesis uses quantitative research with the data used are secondary data for all variables and data on financial ratios contained in BRI Syariah Bank's financial statements in the period 2012-2019. The population in this research is an area that will be investigated by researchers. Population is a generalization environment that consists of objects or subjects that have the quality and characteristics that have been preserved by the researcher which will be studied and then conclusions will be drawn (Sugiyono, 2011). The population that will be used in this study is the monthly financial statements of Islamic financial institutions, namely PT. BRI Syariah Bank in 2012-2019.

The sample used in this study was obtained by purposive sampling method. The criteria in sample selection are: Bank BRI Syariah has a positive ROA, the BRI Syariah Bank made quarterly published financial statements in the 2012-2019 period and was published by Bank Indonesia, and data for this study is available between 2012-2019 in the form of quarterly financial statements, which are 32 samples.

Data collected in this study are secondary data so that the techniques or methods of data collection use non-participant observation. Non participant observation is an observation in which the researcher does not participate directly in the activity or process being observed.

\section{Result and Discussion}

\subsection{Descriptive Statistics of Research Variables}

\begin{tabular}{cccccc}
\multicolumn{7}{c}{ Table 1. Descriptive Statistics Test } \\
Descriptive Statistics \\
\hline N & Minimum & Maximum & Mean & Std. Deviation \\
\hline CAR & 32 & 11,03 & 29,79 & 18,1397 & 6,13477 \\
NPF & 32 & 1,84 & 4,97 & 3,5222 & 0,89231 \\
DPK & 32 & 2,39 & 9,01 & 4,8566 & 1,42265 \\
SB & 32 & 4,25 & 7,75 & 6,0703 & 1,14518 \\
ROA & 32 & 0,03 & 1,71 & 0,7556 & 0,42107 \\
Valid N (listwise) & 32 & & & \\
\hline \multicolumn{7}{c}{ Source: Secondary data processed (2020) }
\end{tabular}

Based on the SPSS program output above, the following results are obtained:

From 32 data samples, the CAR variable has a minimum value of 11.03 and a maximum value of 29.79. The mean value of the CAR for this 8-year period is 18.1397 and the standard deviation value is 6.13477 . From 32 data samples, the NPF variable has a minimum value of 1.84 and a maximum value of 4.97 . The mean value of the CAR for this 8 -year period is 3.5222 and the standard deviation is 0,89231 . From 32 data samples, the TPF variable has a minimum value of 2.39 and a maximum value of 9.01 . The mean value of deposits in this 8 year period is 4.8566 and the standard deviation is 1.42265 . From 32 data samples, the Interest Rate variable has a minimum value of 4.25 and a maximum value of 7.75 . The mean value of the Interest Rate for this 8 year period is 6.0703 and the standard deviation value is 1.14518 . From 32 data samples, the ROA variable has a minimum value of 0.03 and a maximum value of 1.71 . The mean value of ROA for this 8 year period is 0.7556 and the standard deviation value is 0.42107 . 


\subsection{Classical Assumption Testing Results}

Table 2. Kolmogorov-Smirnov

One-Sample Kolmogorov-Smirnov Test

\begin{tabular}{lll}
\hline & & Unstandardized Residual \\
\hline $\mathrm{N}$ & & 32 \\
Normal Parameters & Mean & 0,0000000 \\
& Std. Deviation & 0,32386882 \\
Most Extreme Differences & Absolute & 0,122 \\
& Positive & 0,082 \\
& Negative & $-0,122$ \\
Kolmogorov-Smirnov Z & & 0,690 \\
Asymp. Sig. (2-tailed) & & 0,727 \\
a. Test distribution is Normal. & \\
b. Calculated from data. & \\
\hline \multicolumn{2}{c}{ Source: Secondary data processed (2020) }
\end{tabular}

Source: Secondary data processed (2020)

Based on the results in Table 2 above, it shows that the data is normally distributed. This is indicated by the Kolmogorov-Smirnov value of 0.690 and the significance at 0.727 which is greater than $\alpha 0.05$. Regression model declared free from multicollinearity is if it has a Tolerance value greater than 0.1 and a VIF value smaller than 10 . The data used for this multicollinearity test is data from all four independent variables. In this study it was found that all independent variables have a Tolerance value greater than 0.1 and a VIF value smaller than 10. Thus in this model there are no multicollinearity problems. If $\mathrm{dU}<\mathrm{d}<2$, it means that there is no positive or negative autocorrelation. Based on the above results it is concluded that $1.7323<1,842<2$, it means that there is no autocorrelation, positive or negative. In other words this study passed the autocorrelation test. In this study the results obtained that the significance value for all independent variables used in this study is greater than $\alpha=0.05$. It can be concluded that in the regression transformation equation used heteroscedasticity does not occur.

\subsection{Partial Influence}

CAR variable significance value of $0.616>\alpha 0.05$ and $t$ arithmetic $0.507<\mathrm{t}$ table 2.03693 . So it can be interpreted that the CAR value does not significantly influence ROA. So H0 is accepted and H1 is rejected. In this case, CAR in the sense of capital is not channeled towards financing so that capital cannot be productive and profitability does not increase, meaning that the size and size of the CAR ratio will not affect the high and low ROA. Thus, based on the results of data processing and empirical condition analysis, it can be concluded that the capital adequacy ratio proxied by CAR has no effect on ROA.

$\mathrm{NPF}$ variable significance value of $0.009<0.05$ and $\mathrm{t}$ arithmetic $=2.834>\mathrm{t}$ table $=2.03693$ so it can be interpreted that the NPF variable has a significant effect on ROA. So H2 is accepted. Thus, based on the results of data processing and analysis of empirical conditions, it can be concluded that the indicators of bank credit risk (financing) proxied by NPF negatively affect ROA.

Deposits variable significance value of $0.199>0.05$ and $\mathrm{t}$ arithmetic $=1.318<\mathrm{t}$ table $=$ 2.03693 so that it can be interpreted that the variable TPF has no significant effect on ROA. So H0 is accepted. DPK is a source of liquidity to facilitate financing contained in bank balance sheet assets. The greater the existing savings, the bank will be able to distribute large 
funding as well. DPK is a fund that comes from the community and is the largest source of funds by banks (Ryad, 2017). Whereas in this research at BRI Syariah Bank, DPK has no effect on ROA, this can be caused by an imbalance between the amount of incoming funding sources and the amount of funding channeled to the public.

Interest Rate Variables the significance value is $0.473>0.05$ and $\mathrm{t}$ arithmetic $=0.728<\mathrm{t}$ table $=2.03693$ so it can be interpreted that the Interest Rate variable has no significant effect on ROA. So H0 is accepted. In this study, interest rates do not affect ROA, this can be caused by basically the operational system of Islamic Banks that do not use interest so that the interest rate (BI Rate) does not affect ROA.

This study aims to determine the effect of CAR, NPF, DPK and Interest Rates simultaneously on ROA. Based on the results of the above analysis, it is known that the regression analysis produces an Adjusted R-Square value of 0.321, meaning that the CAR, NPF, DPK, and Interest Rate variables have a proportion of influence on ROA of $32.1 \%$ while the remaining $67.9 \%(100 \%-32,1 \%)$ influenced by other variables that are not in the linear regression model. The results also show that the expected significance is 0.005 or smaller than 0.05, which means CAR, NPF, DPK and Interest Rates simultaneously influence ROA.

\section{Conclusions}

Based on the results of the data analysis and discussion described in the previous chapter, the conclusions of this study are: CAR variable has no significant effect on ROA, this is evidenced by the significance value of $0.616>\alpha 0.05$ and $t$ arithmetic $0.507>t$ table 2.03693 . so it can be interpreted that the CAR value does not significantly influence ROA. So H0 is accepted and H1 is rejected. The NPF variable has a negative and significant effect on ROA, this is evidenced by the significance value of $0.009<0.05$ and $\mathrm{t}$ arithmetic $=2.834>\mathrm{t}$ table $=$ 2.03693 so it can be interpreted that the NPF variable has a significant effect on ROA. So H0 is rejected H2 is accepted. TPF variable does not significantly influence ROA, this is evidenced by the significant value of $0.199>0.05$ and $t$ arithmetic $=1.318<\mathrm{t}$ table $=2.03693$ so it can be interpreted that TPF variable does not significantly influence ROA. So H0 is accepted and $\mathrm{H} 3$ is rejected. Interest Rate variable does not significantly influence ROA, this is evidenced by the significance value of $0.473>0.05$ and $\mathrm{t}$ arithmetic $=0.728<\mathrm{t}$ table $=$ 2.03693 so it can be interpreted that the Interest Rate variable does not significantly influence ROA. So H0 is accepted and H4 is rejected. Variable CAR, NPF, DPK and Interest Rates together have a significant effect on ROA, this is evidenced through the F Test which results in the significance value of $0.005<\alpha=0.05$ and $\mathrm{F}$ arithmetic $=4.660>\mathrm{F}$ table $=2.668437$ means CAR, NPF, DPK, and Interest Rates simultaneously affect ROA. So H5 is accepted and $\mathrm{H} 0$ is rejected. The effect of CAR, NPF, DPK, and Interest rates on ROA was $32.1 \%$. This is evidenced by the Adjusted R-Square value of 0.321 meaning that the CAR, NPF, DPK, and Interest Rate variables have a proportion of influence on ROA of $32.1 \%$ while the remaining $67.9 \%(100 \%-32.1 \%)$ is influenced by other variables which is not in the linear regression model.

\section{References}

[1] Anto, Anto, and M. Ghafur Wibowo. "Faktor-faktor penentu tingkat profitabilitas Bank Umum Syariah di Indonesia." La_Riba: Jurnal Ekonomi Islam 6.2 (2012): 147-160. 
[2] Heri, Sudarsono. "Bank dan Lembaga Keuangan Syariah." Ekonisia, Yogyakarta (2003).

[3] Dendawijaya, Lukman. "Manajemen perbankan." (2009).

[4] Kalengkongan, Glenda. "Tingkat suku bunga dan inflasi pengaruhnya terhadap Return on Asset (ROA) pada industri perbankan yang go public di Bursa Efek Indonesia." Jurnal EMBA: Jurnal Riset Ekonomi, Manajemen, Bisnis Dan Akuntansi 1.4 (2013).

[5] Mahmudah, Nurul, and Ririh Sri Harjanti. "Analisis Capital Adequacy Ratio, Financing To Deposit Ratio, Non Performing Financing, Dan Dana Pihak Ketiga Terhadap Tingkat Profitabilitas Bank Umum Syariah Periode 2011-2013." Prosiding Seminar Nasional IPTEK Terapan (SENIT) 2016 Pengembangan Sumber Daya Lokal Berbasis IPTEK. Vol. 1. No. 1. (2016).

[6] Nuryanto, Rahmat, Muhammad Tho'in, and Herlina Kusuma Wardani. "Rasio Likuiditas, Rasio Solvabilitas, Rasio Rentabilitas Koperasi Jasa Keuangan Syariah Di Jawa Tengah." Jurnal Akuntansi dan Pajak 15.01 (2014).

[7] Nuvrizal, Muhammad Fajrul, and Meutia Fitri. "Faktor-Faktor yang Mempengaruhi Pengungkapan Corporate Social Responbility (CSR) pada Perusahaan yang Terdaftar di Jakarta Islamic Index (JII) tahun 2012-2015 dengan Menggunakan Islamic Social Reporting (ISR) Index sebagai Tolok Ukur." Jurnal Ilmiah Mahasiswa Ekonomi Akuntansi 1.2 (2016): 177-189.

[8] Sofyan, Syafri Harahap. "Analisis Kritis Atas Laporan Keuangan." Jakarta: PT Rajagrafindo Persada (2013).

[9] Sugiyono, Dr. "Metode penelitian kuantitatif dan R\&D." Bandung: Alfabeta (2010).

[10] Tho'in, Muhammad, Tri Irawati, and Mika Lee. "Risk and Financial Health Level of Shariabanking." Journal Research and Analysis: Economy 1.1 (2018): 19-26.

[11] Tho'in, Muhammad. "Profitability of Islamic Commercial Banks in Indonesia." MEC-J (Management and Economics Journal) 3.3 (2019): 277-288.

[12] Tho'in, Muhammad. "Analysis of Islamic Bank's Soundness Level Using Capital Ratio, Profitability, Financing, And Credit Risk (2020).

[13] Widyawati, Giofani Nursucia, and Mohammad Djazari. "Pengaruh Capital Adequacy Ratio (CAR), Non Performing Financing (NPF), Operational Efficiency Ratio (OER), Penyisihan Penghapusan Aktiva Produktif (PPAP) dan Net Operating Margin (NOM) Terhadap Profitabilitas Pada Bank Umum Syariah Periode 2010-2015." Jurnal Profita: Kajian Ilmu Akuntansi 5.2 (2017).

[14] Winda, Winda, Sugianto Sugianto, and Nur Ahmadi Bi Rahmani. "Faktor-Faktor yang Mempengaruhi Return On Assets PT. Bank Rakyat Indonesia Syariah." Al-Masharif: Jurnal Ilmu Ekonomi dan Keislaman 8.1 (2020): 149-161.

[15] Yudiana, Fetria Eka Yudiana. Manajemen Pembiayaan Bank Syariah. STAIN Salatiga Press, (2014). 